\begin{tabular}{ll}
\hline 臨 & 床 \\
\hline
\end{tabular}

\title{
中耳手術症例に拉ける内耳瘻孔の検討
}

\author{
田辺 牧人・山本 悦生・过純・篠原 尚吾 \\ 宗田 由紀・坂本 達則・金 泰秀
}

\section{Labyrinthine Fistula in Middle Ear Diseases}

\author{
Makito Tanabe, Etsuo Yamamoto, Jun Tsuji, Shogo Shinohara, \\ Yuki Muneta, Tatsunori Sakamoto and Tesu Kim \\ (Kobe City General Hospital)
}

Fifty-one ears with labyrinthine fistulas underwent surgery in our hospital between May 1987 and December 1997. Forty-eight of the 51 ears had middle ear cholesteatoma, 2 had chronic otitis media, and 1 had eosinophilic granuloma. The fistulas were located in the lateral semicircular canal in 47 ears, in the cochlea in 2 ears, in the anterior semicircular canal in 1, and in both the lateral and anterior semicircular canals in 1 . Labyrinthine fistulas were detected by temporal bone computed tomography (CT) in 35 of 40 ears tested (87.5\%), indicating that temporal bone CT is necessary before surgery for middle ear disease. In patients with dizziness before surgery, bone conduction tended to be worse before and after surgery than in patients without dizziness. Inflammatory granulation tissue and a cholesteatoma matrix over the fistula should be removed at surgery, and the fistula should be covered immediately; this will prevent postoperative impairment of inner ear function. In 41 ears (about $80 \%$ ), destruction of bone in other sites, such as facial canal dehiscence or exposure of the middle fossa dura or the sigmoid sinus, was detected at surgery.

Key words : labyrinthine fistula, cholesteatoma, computed tomography, dizziness, destruction of bone

はじめに

中耳手術の際に内耳瘦孔のある症例に遭遇することは まれではない，術前からすでに難聴, 眩暈感などの内耳 障害をさたしている例もあれば，術前にはとれらをほと んど認めない例もある. 中耳手術中の内耳瘦孔に対する 処理は現在も論議のあるところであり，術後に内耳機能 がどのよらに変化するかも興味のあるところである. そ こで今回は中耳手術時に内耳瘻孔を認めた症例の特徽を 調べ，今後の中耳手術の参考にしたいと考えた.
対象と方法

昭和 62 年 5 月から平成 9 年 12 月までの 10 年 8 力月間の 間に当科で初回中耳手術を行った1515耳中，手術時に内 耳瘦孔が確認できた51耳(3.4\%)を対象とした．骨壁が 薄くなり膜迷路が透見できる，いわゆるブルーライン症 例は除外した。

これら内耳瘦孔症例の原疾患, 瘦孔の部位, 側頭骨タ一 ゲット CT (以下側頭骨 CT とする)上の㾇孔の有無, 術 前後の平均骨導閾值(会話音域 $500 \mathrm{~Hz}, 1 \mathrm{kHz}, 2 \mathrm{kHz}$ の 3 分法平均, 以下骨導閾值とする), 眩量感の有無, 内 耳瘦孔の処理法, 他の部位の骨欠損の有無について検討 
した。

原疾患は慢性中耳炎 (鼓室硬化症, 癒着性中耳炎, コ レステリン肉芽腫等を含む), 中耳真珠腫(以下真珠腫と し，弛緩部から陥凹寸る弛緩部型，緊張部から陥凹寸る 緊張部型，広範囲の進展などで分類不能な混合型，先天 性の 4 型に分類した)，その他(耳小骨奇形，腫瘍など） に分類した．他の部位の骨欠損については顔面神経管の 骨欠損，中耳腔上方(以下天蓋とする)の骨欠損による硬 膜露出, 乳突腔後方 (以下 $S$ 状洞壁とする)の骨欠損によ るS 状静脈洞露出について調べた.

\section{結果}

対象症例の性別は男性 28 耳，女性 23 耳，年齢は $4 \sim 73$ 歳であった。

疾患の内訳は真珠腫が51耳中 48 耳 $(94.1 \%)$ と汪とんど を占めた。 そのなかでも緊張部型が 26 耳と真珠腫の半数 以上を占め, 次いで弛緩部型 15 耳, 混合型 4 耳, 先天性 3 耳となった。.以下慢性中耳炎は 2 耳 $(3.9 \%)$, その他(好 酸球肉芽腫) 1 耳 $(2.0 \%)$ であった．対象期間の各疾患の 症例全体の中で内耳瘦孔のあった症例の割合は, 真珠腫 はその全体の $8.6 \%$ (緊張部型は全体の $12.1 \%$ ，弛緩部型 $6.0 \%$, 混合型 $10.6 \%$, 先天性 $5.9 \%)$, 慢性中耳炎は全 体の $0.3 \%$ であった(図 1 ).
内耳瘦孔の部位の内訳は, 外側半規管のみに瘦孔を認 めた例が 47 耳 $92.2 \%$ と大半を占め, 蝸牛のみに 2 耳, 前 半規管のみに 1 耳, 外側半規管と前半規管の両方に瘦孔 のあった例が 1 耳であった。

術前に側頭骨 CT を撮影していた40耳について，内耳 (蝸牛拈よび半規管) 周囲の骨欠損といった内耳瘦孔を疑 ら所見を認めたものは，35耳(87.5\%)であった。

内耳障害については，術前に何らかの眩暈感を伴って

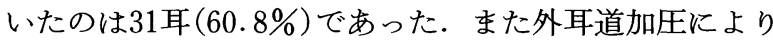
その同側向きの，減圧により反対側向きの眼振が認めら れる瘦孔症状は15耳中 5 耳 $(33.3 \%)$ が陽性であった。術

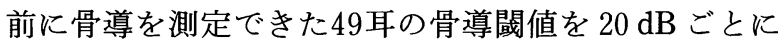
区切ると，表 1 のようになり $20 \mathrm{~dB}$ 未満 10 耳, $20 \mathrm{~dB}$ 以 上 $40 \mathrm{~dB}$ 未満 20 耳, $40 \mathrm{~dB}$ 以上 $60 \mathrm{~dB}$ 未満 9 耳, $60 \mathrm{~dB}$ 以上 10 耳であった．術前に眩暈感のあった例数は術前骨 導閾值が $40 \mathrm{~dB}$ 以上の群の方が $40 \mathrm{~dB}$ 未満の群よりも 多い傾向にあり，術前に眩量感のあった群の骨導閾值の 平均は $39.8 \mathrm{~dB}$, 眩暈感のなかった群の平均は $32.8 \mathrm{~dB}$ で，有意差はないが眩量感のある方が骨導閾值が高い傾 向にあった(マン・ホイットニーのU検定 : $\mathrm{P}=0.14)$. これら内耳機能の術後の変化は, 眩量感については最終 的には 1 耳を除いて消失した。この 1 耳は対象症例中最 高齢の73歳であり, 術後のシェロングテストが陽性で

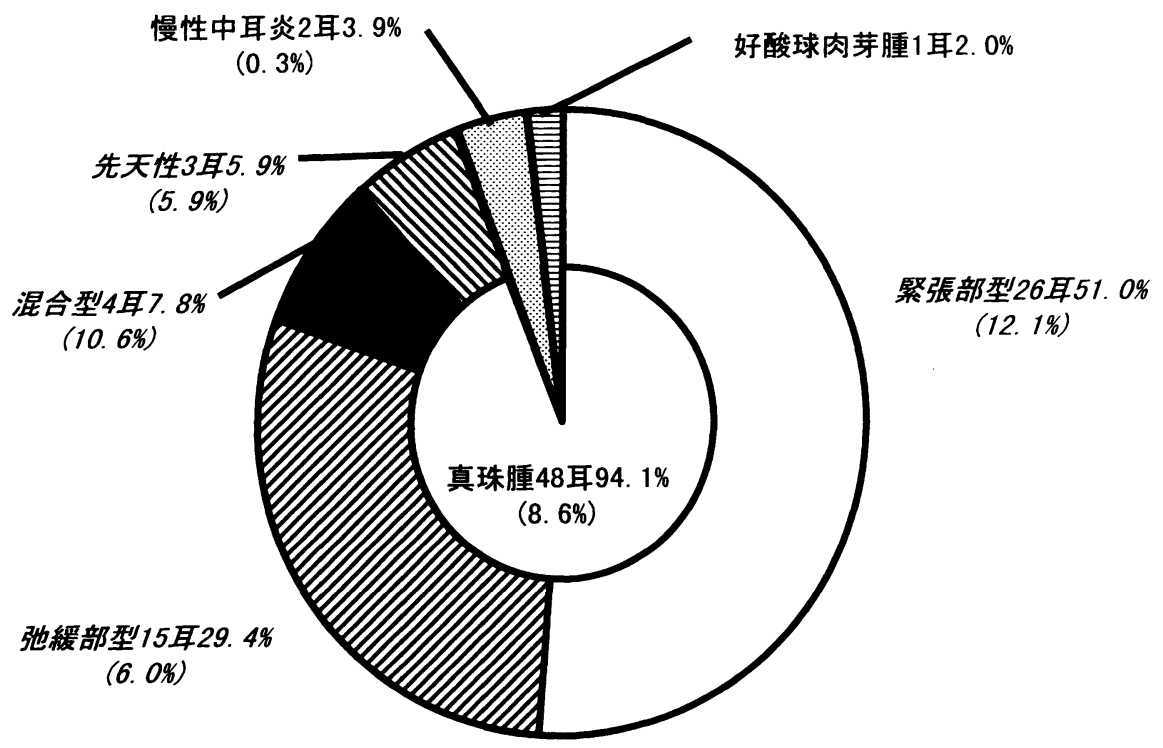

図 1 内耳瘦孔例の疾患の内訳

各疾患名, 耳数, 内耳瘦孔全体に対する割合を示す，カッコ内は各疾患全体に対 寸る内耳瘦孔例の割合. 斜字体は真珠腫の各分類. 
表 1 内耳瘦孔症例の術前内耳機能(眩暈感の有無と骨導閾値)

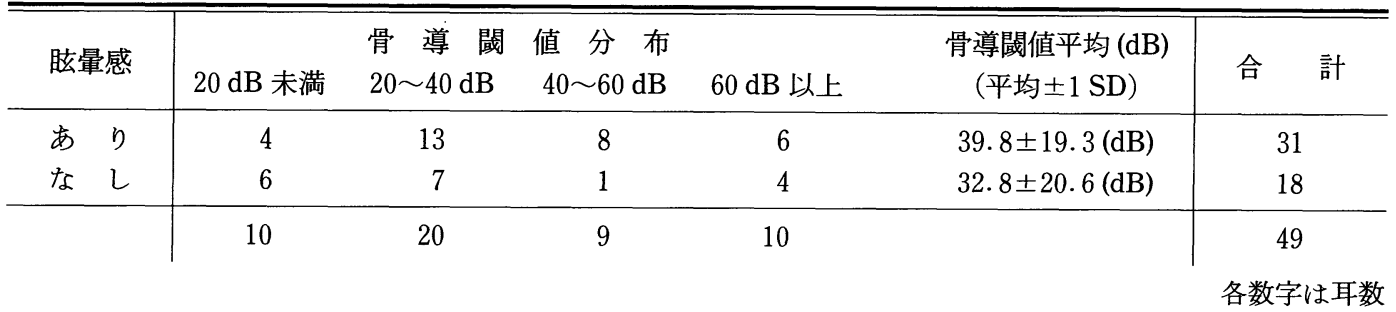

あった，骨導間值が術後に $15 \mathrm{~dB}$ 以上閾値上昇したの は 3 耳あり，その 3 耳はすべて術前に眩量感のあった症 例であった。

われわれは内耳瘦孔上の病変の処理は, 基本的には一 期的に除去することにして括り，今回の症例でも全例で 一期的に肉芽や真珠腫上皮を除去した. 病変除去後の㾇 孔の処理は, 対象期間の前半 (昭和62年から平成 3 年頃 まで)の 29 耳では側頭笳膜を用いて瘦孔を閉鎖した(らち 2 例では側頭筋充填を併用). 後半 (平成 4 年頃から)の 22耳では自家骨片，骨パテを用いて㾇孔を閉鎖した。こ の 2 つの閉鎖法の間には術後の眩量感の有無, 骨導閾値 の変化には明らかな差はなかった。

中耳腔の他の部位の骨欠損の状態は, 内耳瘦孔以外飞 顔面神経管の骨欠損のみが 21 耳, 天蓋の骨欠損のみは 5 耳, 顔面神経管と天蓋の骨欠損の合併は 10 耳, 顔面神経 管と S 状洞壁の骨欠損の合併は 1 耳，顔面神経管，天蓋， $\mathrm{S}$ 状洞壁の骨欠損の合併は 4 耳であった。これらをまと

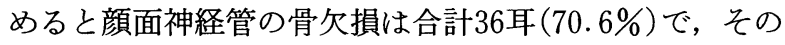
すべての症例で真珠腫などの病変が骨欠損部に接してい た。また天蓋の骨欠損は合計19耳 $(37.3 \%) ， \mathrm{~S}$ 状洞壁の 骨欠損は合計 5 耳 $(9.8 \%)$ であり, 総合すると内耳瘻孔 のある症例は 41 耳 $(80.4 \%)$ と約 8 割で他の骨欠損を合併

\section{していた(表 2 ).}

\section{考 察}

内耳瘦孔を伴ら症例は, 耳手術, 特に真珠腫に対する 手術のなかでは決してまれでなく，今回の検討でも初回

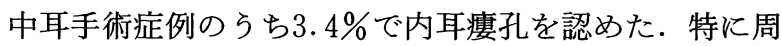
囲の骨破壊を伴う真珠腫では全体の $8.6 \%$ に内耳瘦孔を 認めたが，これまでの報告1) 3) と比較しても大差はな かった. 真珠腫の型別では緊張部型, 混合型が弛緩部型, 先天性と比較して内耳瘦孔を伴う割合が高かった。これ は緊張部型では真珠腫の進展方向に外側半規管があるた めに，弛緩部型よりも骨破壊による内耳癭孔を伴いやす いと考兄られ，混合型は広範囲に進展している例が多い ため内耳瘦孔を伴ら割合が高くなったと考兄られる．慢 性中耳炎は病変による骨破壊が少ないため，内耳瘦孔を 認めたのは慢性中耳炎全体の $0.3 \%$ と真珠腫と比較して かなり少ない割合になったと考觉られる。このように疾 患によって，および真珠腫の型によっても内耳瘦孔を伴 ら割合が違うことは，手術に臨む際に常に念頭に执くべ さであると考兄られる。

内耳瘦孔の部位は，これまでの報告と同様に外側半規 管がもっとも多く大半を占めた ${ }^{1) ~ 8) . ~}$

表 2 内耳瘻孔症例の中耳腔の他の部位の骨欠損

\begin{tabular}{c|ccc|c}
\hline \hline & 顔神管 & 天蓋 & S 状洞壁 & \\
\hline 顔神管のみ & 21 & & & \\
天蓋のみ & & 5 & & \\
顔神管+天蓋 & 10 & 10 & & \\
顔神管+ S 状洞壁 & 1 & & 1 & \\
顔神管+天蓋+S 状洞壁 & 4 & 4 & 4 & \\
\hline & $36(70.6 \%)$ & $19(37.3 \%)$ & $5(9.8 \%)$ & 延べ 41 (80.4\%)
\end{tabular}


術前の画像診断については, 側頭骨 CT や MRI で内 耳瘦孔をかなり診断できるようになり，最近の報告でる 画像診断による診断率は高くなって扣り，80\%前後から 全例診断できたといら報告318) もある. 当科では側頭骨 CT 導入後, 支障がない限り中耳手術前に全例で側頭骨 $\mathrm{CT}$ (軸位断)を撮影し, 可能な限り冠状断も撮影してい る. 内耳㾇孔の診断には冠状断 CT p MRI の T2 強調 画像が特に有効であるとの報告2) があり，今回のわれわ れの検討で側頭骨 CT での内耳瘦孔の診断率(感度)が $87.5 \%$ と比較的高率であったのも, 軸位断だけでは内耳 㾇孔を診断できず，冠状断で診断できていた例があった ためと考兄られる.これらのことから特に真珠腫や腫瘍 のように骨破壊性の疾患の術前には, 少なくとも軸位断 だけでなく冠状断の側頭骨 CT を撮影するべきと考兄ら れる。

内耳瘦孔を伴うような症例では, 内耳機能が何らかの 障害を受けている可能性がある. 平衡機能の指標として 眩暈感は術前に半数以上で認められたが，瘦孔症状は今 回の検討では陽性率が33.3\%であった。これまでの報 告3) 6) でも内耳瘦孔を伴万例での瘦孔症状の陽性率はそ れほど高くなく，補助的な検査とするべきと考兄られる. また蝸牛機能は術前に骨導閾值が $40 \mathrm{~dB}$ 以内であった ものは 30 耳と約 6 割を占め, これまでの報告2)99 と大差 なかった。眩暈感は術後には 1 例のみで残存したが, 73 歳と高齢でシェロングテストも陽性であり, 骨髄異形成 症候群による貧血も伴っていたことから，内耳機能とし ての平衡機能障害が続いているといらより，自律神経系 など内耳以外の要素が大きいと考兄られる，骨導閾值は 術後に $15 \mathrm{~dB}$ 以上上昇したのが 3 耳のみであり，これ までの報告1228) と比較して悪化した割合は少ないといえ る.この 3 耳は術前に眩量感があり，骨導閾値も $40 \mathrm{~dB}$ 以上であったことから, 症例数が少ないので断定的なこ とはい方ないが，眩量感が内耳機能全体の障害を示唆す る可能性があると考兄られる。また術前の骨導閾値平均 と眩量感の有無とは相関する傾向があることから, 術前 に眩量感を伴う症例は術後にその障害, 特に蝸牛機能の 障害が増強する可能性も考兄られ, 術中の操作には特に 注意すべきと考えられた。

内耳瘦孔上の病変処理は論議のあるところで, 病変を 残存させるべきといら報告10)や，除去するにしても二 期的に除去すべきといら報告244)11) がある. 瘦孔への操 作による内耳障害の可能性が病変残存の理由であるが,
逆に Palva ら ${ }^{12)}$ は病変を残存させることで炎症により 術後に骨導閾值が上昇すると報告している。また村田 ら ${ }^{8)}$ は真珠腫上皮の残存により広範囲の再発を認めたと 報告して招り，これらのことから近年では瘦孔上の病変 は積極的除去が支持されている318)。二期的な病変除去 を, Sheehy ら4), Sanna ら ${ }^{11)}$ は内耳障害をきたしにく い安全な方法として勧めて扮り，二期手術の際に残存さ せた真珠腫上皮が消失することもあるといら報告11) も ある．症例を選んで，瘦孔の大きい場合11) や，瘦孔周 囲に感染性の肉芽のある場合2)を二期的にする報告もあ る. しかし内耳瘦孔の処理のためだけの二期的手術は患 者の負担になる場合もあり，われわれは内耳瘦孔の処理 については一期的に病変を除去，瘦孔を閉鎖している. 瘦孔への操作による術後の内耳障害も, Herzog ら ${ }^{13)}$ は 内耳㾇孔上の病変を全例で一期的に除去し，術後に骨導 閾值が上昇したのは 1 耳のみとして拈り，われわれも骨 導閾值上昇は 3 耳のみと決して多くなく，十分に注意し て慎重に操作すれば一期的処理でも問題はなく，この方 が患者の負担も少ないといえる.

瘦孔の閉鎖法については，今回の検討で術後にほぼ全 例で眩暈感が消失したこと, 閉鎖材料によって術後の骨 導閾值上昇の差がなかったことから，筋膜のような軟組 織でも骨片のような硬組織でも，乙っかりと閉鎖すれば 問題ないと考兄れる。しかし骨片といった硬組織によ る閉鎖の方が良いとする報告2)もあり，実際にわれわれ も術後の耳処置の際の眩暈感も骨片で閉鎖した症例の方 が誘発されにくい印象があるので，近年は骨片，骨パテ を用いて閉鎖している.

内耳瘦孔症例では病変が広範囲に進展していることが 多いと考えられ，中耳腔の他の部位の骨欠損を調べたと ころ, 顔面神経管の骨欠損については手術用顕微鏡下に 確認できたのは全体の約 7 割に及んだ. 組織学的検索で は側頭骨標本の $96 \%$ に何らかの顔面神経管の裂陌が確認 できる14) とされているが，手術用顕微鏡下で骨欠損と して確認できるのは病変によるものと裂隙とを合わせて

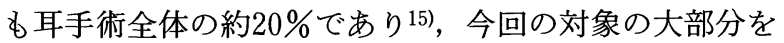
占める中耳真珠腫例でも顔面神経管の骨欠損を確認でき たのは $33 \%$ のである15).それと比較して今回の検討で 骨欠損を確認できた 7 割という割合はかなり頻度が高い といえる。また天蓋や S 状洞壁の骨欠損を含めると, 総 合して対象の約 8 割で中耳腔に内耳癭孔以外の骨欠損に よる重要臟器の露出がみられることになる。これらのこ 
とから内耳㾇孔症例では病変の進展により各部位の骨破 壊が進行していることが多いとい光，このことをふま兄 て術前には側頭骨 CT で骨破壊の状態を把握するととも に, 手術時には十分注意して操作すべきと考兄られた.

$$
\text { まとめ }
$$

当科で行った初回中耳手術1515耳中内耳瘦孔を認めた 51 耳を検討し，以下の結果を得た。

1. 疾患は48耳とほとんどが中耳真珠腫であり,なか でも緊張部型がその半数以上を占めた.

2. 㾇孔の部位は外側半規管が47耳であった。

3. 術前側頭骨 CT で約 $88 \%$ の瘦孔を疑ら所見があっ たことから，術前には冠状断子含めた側頭骨 CT を撮影 するべきである.

4. 術前に眩量感のある例では骨導閾値も上昇してい ることが多く，それが術後に悪化しやすい可能性も念頭 に打くべきである。

5. 内耳瘦孔上の病変は一期的に除去しても, しっか りと瘦孔を閉鎖すれば内耳機能の悪化を抑えることがで きる。

6. 約 8 割で他の部位の骨欠損を伴っていたことより, 手術時には内耳瘦孔以外の中耳腔にも骨欠損があること を念頭に执いて慎重に操作すべきである.

本論文の要旨は第 8 回日本耳科学会(平成10年10月 $22 ２ 4$ 日, 仙台)に执いて発表した。

\section{参考文献}

1) 犬塚一男, 坂野立幸, 稲福 繁, 他: 当科に扣ける過去 9 年間の真珠腫迷路瘦孔症例について. 耳鼻臨床 補73:44 $\sim 51,1994$

2 ）飯野ゆき, 中村 寧, 平川治男, 他: 真珠腫による内耳 瘦孔症例の術後聴力. 耳鼻臨床 $88: 31 \sim 36,1995$.

3 ) 前田 学, 斎藤龍介, 中川文夫, 他: 慢性中耳炎症例に扣 ける迷路瘦孔の検討. 耳鼻臨床 $89: 1065 \sim 1070,1996$.

4 ) Sheehy JL and Brackmann DE : Cholesteatoma surgery ; management of the labyrinthine fistula - a case report of
97 cases. Laryngoscope $89: 78 \sim 87,1979$.

5 ) Gormley PK : Surgical management of labyrinthine fistula with cholesteatoma. J Laryngol Otol $100: 1115 \sim 1123$, 1986.

6 ) Ostri B and Bak-Pedersen K : Surgical management of labyrinthine fistulae in chronic otitis media with cholesteatoma by a one-stage closed technique. ORL $51: 295$ 〜299, 1989.

7 ) Palva $\mathrm{T}$ and Ramsay $\mathrm{H}$ : Treatment of labyrinthine fistula. Arch Otolaryngol Head Neck Surg 115 : 804 807, 1989.

8 ）村田潤子, 土井勝美, 小畠秀浩, 他 : 真珠腫性中耳炎に拉 ける内耳瘦孔症例の検討. 日耳鼻 $102: 605 \sim 612,1999$.

9) Kim CS, Chung JW and Lee JW : An analysis of labyrinthine fistula in chronic otitis media with cholesteatoma. In Cholesteatoma and Mastoid Surgery (ed by Nakano Y). pp 537 540, Kugler Publications, Amsterdam/New York, 1992.

10) Ritter FN : Chronic suppurative otitis media and the pathologic labyrinthine fistula. Laryngoscope $80: 1025 \sim$ 1035, 1970.

11) Sanna M, Zini C, Bacciu S, et al : Closed vs open technique in the management of labyrinthine fistulae. In Cholesteatoma and Mastoid Surgery (ed by Tos M, Thomsen J and Peitersen E). pp 1043 1045, Kugler \& Ghedini publications, Amsterdam · Berkeley $\cdot$ Milano, 1988.

12) Palva P, Karja J and Palva A : Opening of the labyrinth during chronic ear surgery. Arch Otolaryngol $93: 75 \sim$ 78, 1971.

13) Herzog JA, Smith PG, Kletzker GR, et al : Management of labyrinthine fistulae secondary to cholesteatoma. Am J Otol $17: 410 \sim 415,1996$.

14）䅖山康夫 : 若年者を主とした顔面神経及び顔面神経管の解 剖組織学的研究. 耳展 32 補 $2: 79 \sim 110,1989$.

15）田辺牧人, 山本悦生, 辻純, 他: 中耳内顔面神経管骨 欠損例の検討. Facial N Res Jpn $18: 39 \sim 41,1998$.

$$
\left.\begin{array}{l}
\text { 原稿受付 : 平成 } 12 \text { 年 } 3 \text { 月 } 8 \text { 日 } \\
\text { 原稿採択 : 平成 } 12 \text { 年 } 4 \text { 月 } 5 \text { 日 } \\
\text { 別刷請求先 : 田辺牧人 } \\
\text { 干 } 650-0046 \text { 神戸市中央区港島中町4-6 } \\
\text { 神戸市立中央市民病院耳鼻咽喉科 }
\end{array}\right)
$$

